\title{
Preface, 1973
}

B UT haven't things changed, I'm asked, in the some twenty years since you wrote this book?

Yes.

Last summer the Farmers' Association of Fujinomiya, a town at the foot of Fujiyama, chartered a plane, and the farmers flew to Paris for a vacation. Another result of affluence is the National Theatre, opened 1 November 1966, just across the street from the Imperial Palace grounds in Tokyo. A handsome, superbly equipped building, it is dedicated to preserving, promoting, and developing Japanese traditional theatre arts. Within it are two theatres. The larger, seating 1,746, used principally for Kabuki, provides all the scenes and machines a Kabuki connoisseur could want-both the permanent and the temporary hanamichi of the late eighteenth-century theatre, for example, and the world's largest revolving stage, sixty-five feet in diameter, containing sixteen trap-lifts. The smaller theatre, seating 630 , used to stage a variety of native music and dance, has the special machinery required for doll theatre performances.

Evidence is abundant, however, that new theatre buildings, no matter how elegant and well equipped, do not guarantee compelling performances nor theatrical innovation. The National Theatre engages the foremost Kabuki troupes, presents Kabuki plays in their entirety rather than doing collections of the choicest scenes from them, revives plays that have been neglected, and conducts research on the correct historical methods of production. While preserving the past, the theatre also encourages contemporary playwrights to write pieces based upon the Kabuki form; the most spectacular production of a new play was of that written by Mishima Yukio, which exploited 
contemporary sado-masochistic violence as well as all the scenic and mechanic resources of the National Theatre. The theatre has broken with the past by instituting formal classes in actor training as opposed to the traditional, slow and laborious, teacher-disciple system, with the result that teaching is done rapidly and systematically.

Although Kabuki tickets are increasingly expensive, the houses are full at the National Theatre and elsewhere. Probably a larger percentage of the population now sees Kabuki than ever before. Not live, of course, but on television. The National Theatre either plugs into a relay car outside the building or transmits by microwave from the top of it. And so the television audience could see the entire eleven acts of The Loyal Forty-seven Ronnin, running time about twelve hours. A lot more foreigners have seen Kabuki. It's obligatory for the stylish tourist in Japan, and then the Kabuki's been abroada tour of the United States, 'two tours of Europe-and on the whole critics and audiences were impressed. More has been written about the Kabuki by foreigners in the past twenty years than was before, and one can see, fairly regularly, Kabuki plays produced in English in American university theatres. Kabuki performances don't seem to be dwindling. A Kabuki actor has remarked that if it should disappear in Japan, it will not be lost, for production will go on in the United States.

I solemnly inveighed, I notice, against forcing American notions on the Japanese. True, there was propagandizing in 1945 and later, but the Japanese didn't have their present consumer society forced upon them. They like all the appliances, enjoy built-in obsolescence. Television commercials run even longer than ours. McDonald's flourishes. There seem to be as many knives and forks as chopsticks. The 'Western Room' may survive in a few old houses, but the new ones consist almost entirely of Western rooms. A plastic imitation of traditional straw matting for the floor is available. The tokonoma is not to be found in the high-rise apartments. Factories smoke where rice grew.

But perhaps in historical perspective there is less to this than meets the eye. The Japanese have always loved novelty, whether native or foreign, and have set great store by foreign technology, particularly since 1868. A Japanese film company employee told me in 1946 that he became convinced Japan would lose the war when he saw Disney's Fantasia, a print of which the army had found in Singapore; Mine-san, the cook, couldn't figure out why Japan had lost the war until she 
saw a jeep and henceforth ascribed defeat to that automotive wonder. But the Japanese seem to have the ability to live without schizophrenia both in a traditional Japanese world and in a 'modern' one, a psychological adjustment that doubtless had to be made following 1868. Their modern world, seen in all its hideousness as you leave Haneda airport, is readily discernible. Their traditional world is less obvious, more tenaciously held, a world of habit, of taste. It is the world in which No plays are presented, every weekend in Tokyo, in very much the same way they were costumed, acted, danced, and sung five centuries ago. And the Japanese who goes to the Nō on Sunday may very well have been to an all-Beethoven concert on Saturday.

And so it seems that bad modern taste need not drive out good traditional taste or that Kabuki will vanish because a poor musicalcomedy version of Gone With the Wind played to packed houses.

Japanese theatre has really changed little in the past twenty years. Straight plays, old or new, native or foreign, still run only a month, but the modern actor now adds to his income by working in television, as do some of the young Kabuki actors, who are capable of playing equally well in the realistic mode. Some young actors experiment in off-off-Broadway fashion, but their work attracts even smaller audiences than the conventional play. Although the government pays the staff at the National Theatre, the Kabuki must make its way commercially there as elsewhere. As film eroded the theatre audience, television now erodes the film audience. Foreign theatreworkers urge the Japanese to preserve the Nō, preserve the Kabuki, and some Japanese wonder how or why.

But No and Kabuki go on, like the tea ceremony, the doll theatre, court music and dance, and the pinball machine, which is no longer a fad but an institution. A sizable number of Japanese find deep satisfaction in them.

In October 1972 one could step out of the din and pollution of Tokyo into the Kabuki-za to see Kichiemon's grandson play Togashi in The Subscription List, a role in which his grandfather excelled. He's not yet as good as his grandfather was, but he will be. The set was precisely the same as it's always been and so was the music. The audience was perhaps a little more restrained than the one grandfather played to, but they came and went at will, they ate, and some seemed to have little notion of what was going on theatrically, though whatever it was, it was estimable. And there were those, 


\section{THE KABUKI THEATRE}

perhaps a majority, who shed tears when Yoshitsune forgives Benkei for having struck him. As long as audiences weep at that moment of the play, a moment so purely Japanese that it is emotionally inaccessible to most foreigners, traditional Japanese sensibility will be alive and the Kabuki will nourish it.

EARLE ERNST

Honolulu, Hawaii

15 October 1978 